\title{
Phosphatase production and activity in Citrobacter freundii and a naturally occurring, heavy-metal-accumulating Citrobacter sp.
}

\author{
Diana M. Montgomery, ${ }^{1}$ Alastair C. R. Dean, ${ }^{1}$ Paul Wiffen ${ }^{2}$ and \\ Lynne E. Macaskie ${ }^{2}$
}

Author for correspondence: Lynne E. Macaskie. Tel: +44 121414 5889. Fax: +441214146557.

1 Physical Chemistry Laboratory, University of Oxford, South Parks Road, Oxford OX1 3QZ, UK

2 School of Biological Sciences, University of Birmingham, Edgbaston, Birmingham B15 2TT, UK
The ability of a naturally occurring Citrobacter sp. to accumulate cadmium has been attributed to cellular precipitation of $\mathrm{CdHPO}_{4}$, utilizing $\mathrm{HPO}_{4}^{2-}$ liberated via the activity of an overproduced, Cd-resistant acid-type phosphatase.

Phosphatase production and heavy metal accumulation by batch cultures of this strain (N14) and a phosphatase-deficient mutant were compared with two reference strains of Citrobacter freundif. Only strain N14 expressed a high level of acid phosphatase and accumulated lanthanum and uranyl ion enzymically. Acid phosphatase is regulated via carbon-starvation; although the $C$. freundii strains overexpressed phosphatase activity in carbon-limiting continuous culture, this was approximately 20-fold less than the activity of strain N14 grown similarly. Citrobacter strain N14 was originally isolated from a metalcontaminated soil environment; phosphatase overproduction and metal accumulation were postulated as a detoxification mechanism. However, application of Cd-stress, and enrichment for Cd-resistant $C$. freundii ('training'), reduced the phosphatase activity of this organism by about $50 \%$ as compared to $\mathrm{Cd}$-unstressed cultures. The acid phosphatase of $\mathrm{C}$. freundii and Citrobacter N14 had a similar pattern of resistance to some diagnostic reagents. The enzyme of the latter is similar to the PhoN acid phosphatase of Salmonella typhimurium described by other workers; the results are discussed with respect to the known phosphatases of the enterobacteria.

Keywords: Citrobacter, phosphatase, heavy metals, cadmium resistance

\section{INTRODUCTION}

Strains of Citrobacter spp. isolated from lead-contaminated soil (Aickin \& Dean, 1979; Macaskie \& Dean, 1982, 1984) accumulated heavy metals when resuspended in metal-supplemented solution (Aickin \& Dean, 1979; Macaskie \& Dean, 1984). Metal uptake is mediated via the activity of an overproduced acid-type phosphatase, induced during pre-growth, that functions also in nongrowing, resuspended cells and in immobilized cells to liberate $\mathrm{HPO}_{4}^{2-}$ from appropriate organic phosphate 'donor' molecules (substrates) with precipitation of heavy metals as (e.g.) $\mathrm{PbHPO}_{4}$ (Aickin et al., 1979), $\mathrm{CdHPO}_{4}$ (Macaskie et al., 1987) or $\mathrm{UO}_{2} \mathrm{HPO}_{4}$ (Macaskie et al., 1992 ) at the cell surface. The lead-accumulating and cadmium-accumulating Citrobacter spp. were different isolates, as suggested by their respective responses to a range of standard biochemical tests (strain identification reports, National Collection of Industrial and Marine
Bacteria, 1978, 1981) and in the inability of the leadaccumulating strain to accumulate $\mathrm{Cd}^{2+}(\mathrm{R}$. M. Aickin, L. E. Macaskie \& A. C. R. Dean, unpublished). In contrast, the $\mathrm{Cd}$-accumulating strain was non-specific with respect to the metals accumulated; these included $\mathrm{Cd}^{2+}, \mathrm{Pb}^{2+}$, $\mathrm{Cu}^{2+}, \mathrm{Sr}^{2+}, \mathrm{UO}_{2}^{2+}$ (Macaskie, 1990), $\mathrm{Mn}^{2+}$ (Clark et al., 1992, 1993), $\mathrm{La}^{3+}, \mathrm{Am}^{3+}, \mathrm{Th}^{4+}$ and $\mathrm{Pu}^{4+}$ (Macaskie et al., 1994a), and the potential of this strain in the bioremediation of metal- and radionuclide-contaminated wastes has been suggested (Macaskie et al., 1994a).

Since two separate Citrobacter strains were isolated from the metal-polluted site it was of interest to establish whether the phosphatase overproduction and metalaccumulative properties are unique to these strains (possibly selected via metal stress) or are a more general feature of the genus Citrobacter. Silver uptake using a Citrobacter sp. was identical from substrate-supplemented and substrate-free suspensions, discounting a major role 
for phosphatase in this case (Goddard \& Bull, 1989), while other studies have demonstrated Citrobactermediated accumulation of uranyl ion (Watson \& Ellwood, 1987; Bahaj et al., 1989); it was not clear to what extent phosphatase activity was contributory.

One hypothesis suggests that prolonged exposure to heavy metals can elicit phosphatase overproduction as a detoxification mechanism, with precipitation of metals away from sensitive cellular sites. Additionally, the $\mathrm{Cd}$ resistance of the enzyme (Hambling et al., 1987) suggests that the enzyme itself may have evolved a metal tolerance. These predictions were tested in the present study, which also sought to investigate other possible differences in the phosphatase enzyme(s) of the naturally occurring isolate as compared to standard strains of $C$. freundii obtained from a culture collection and grown in batch and continuous culture.

\section{METHODS}

Micro-organisms. Citrobacter sp. strain N14 was isolated from a site contaminated with lead as described previously (Macaskie \& Dean, 1982) and was identified to genus level by staff of the National Collections of Industrial and Marine Bacteria (NCIMB: Torry Research Station, Aberdeen, UK). Cultures were routinely checked using the API $20 \mathrm{E}$ system of classification (API Products), and differed from the normal Citrobacter response to the lysine decarboxylase test; the high diversity of soil Citrobacters has been noted by Farmer (1981). Screening for plasmids was done by Dr L. Diels (VITO, Mol, Belgium); none were found. The phosphatase-deficient mutant lp4a was as described previously (Macaskie et al., 1994a). The phosphatase deficiency of the mutant was confirmed by assay and by immunogold staining (Jeong, 1992). The type strains of Citrobacter, Citrobacter freundii NCIMB 11490 and Citrobacter intermedius NCIMB 7271, were obtained from the NCIMB. C. intermedius NCIMB 7271 has since been redesignated as $C$. freundii (NCIMB Catalogue, 1990).

Growth of the organisms. The Citrobacter strains were maintained aerobically at $30^{\circ} \mathrm{C}$ by daily subculture in minimal medium of the following composition $\left(\mathrm{g} \mathrm{l}^{-1}\right)$ : Tris-base, 12.0; $\left(\mathrm{NH}_{4}\right)_{2} \mathrm{SO}_{4}, 0.96$; glycerol 2-phosphate (disodium salt hydrate, $\left.5.5 \mathrm{H}_{2} \mathrm{O}\right), 0 \cdot 67 ; \mathrm{KCl}, 0 \cdot 62 ; \mathrm{MgSO}_{4} .7 \mathrm{H}_{2} \mathrm{O}, 0.063 ; \mathrm{FeSO}_{4} .7 \mathrm{H}_{2} \mathrm{O}$, 0.00032 ; glycerol, 1.5 or as otherwise specified; $\mathrm{pH}$ adjusted to $7 \cdot 0$ with $2 \mathrm{M} \mathrm{HCl}$. The $\mu_{\max }$ (maximum specific growth rate) was determined in fully adapted cultures in this medium. 'Training' to $\mathrm{Cd}^{2+}$ resistance was done by sequential batch subculture in minimal medium supplemented with progressively increasing concentrations of $\mathrm{Cd}^{2+}$ to a final $\mathrm{Cd}^{2+}$ concentration of $100 \mu \mathrm{g} \mathrm{ml}^{-1}(0.89 \mathrm{mM})$. The maximum specific growth rate in $\mathrm{Cd}$-medium was determined after 10 subcultures at $50 \mu \mathrm{g} \mathrm{Cd}^{2+}$ $\mathrm{ml}^{-1}$ and then 10 subcultures at $100 \mu \mathrm{g} \mathrm{ml}^{-1}$ via progressive steps of $65 \mu \mathrm{g} \mathrm{ml}^{-1}$ (five subcultures), $80 \mu \mathrm{g} \mathrm{m}$ l1 $^{-1}$ (nine subcultures) and $90 \mu \mathrm{g} \mathrm{ml}^{-1}$ (two subcultures).

Continuous culture. Carbon-limiting and phosphate-limiting media were as above, except that the concentrations of glycerol and glycerol 2-phosphate were reduced to 0.6 and $0.066 \mathrm{~g} \mathrm{l}^{-1}$ respectively; in the latter medium the concentration of glycerol was increased to $3 \mathrm{~g} \mathrm{l}^{-1}$. Polypropylene glycol antifoam was incorporated at $1 \mathrm{ml}$ per $10 \mathrm{l}$ of medium. The cultures were maintained at $30^{\circ} \mathrm{C}$ in a New Brunswick 'Bioflo' apparatus (agitation 400 r.p.m., air flow $0.51 \mathrm{~min}^{-1}$ ) at a dilution rate corresponding to $D=0.5 \mu_{\max }$. This was equivalent to $D=$
$0 \cdot 25 \mathrm{~h}^{-1}$ for Citrobacter N14, D $=0.28 \mathrm{~h}^{-1}$ for $C$. freundii NCIMB 11490 and $D=0.32 \mathrm{~h}^{-1}$ for $C$. freundii NCIMB 7271. The $\mathrm{pH}$ of phosphate-limited cultures tended to fall; this was held at $\mathrm{pH} 7$ using an automated feed of $\mathrm{NaOH}(2 \mathrm{M})$. Steady states were reached in the chemostats after 24 generations of growth, after which the chemostat outflows were collected at $0{ }^{\circ} \mathrm{C}$.

Harvesting and storage of the cells. The cells were harvested from batch cultures in the mid-exponential phase $\left(\mathrm{OD}_{600} 0 \cdot 4\right.$ approx.), or from the chemostat outflows, by centrifugation, washed in isotonic saline $\left(8.5 \mathrm{~g} \mathrm{NaCl} \mathrm{l}^{-1}\right)$ and stored at $4{ }^{\circ} \mathrm{C}$, as described previously (Hambling et al., 1987).

Assay of phosphatase activity. Phosphatase activity was estimated in triplicate samples by the liberation of $p$-nitrophenol from $p$-nitrophenyl phosphate (disodium salt; $\mathrm{BDH}$ ) as described by Bolton \& Dean (1972). Samples (1 ml) of concentrated bacterial suspension $(1 \cdot 2-2 \cdot 4 \mathrm{mg}$ bacterial dry weight $\mathrm{ml}^{-1}$ in isotonic saline) were diluted to $10 \mathrm{ml}$ in appropriate buffer (below). Magnesium chloride $(0.1 \mathrm{ml}$ of $0.15 \mathrm{mM}$ $\left.\mathrm{MgCl}_{2} \cdot 6 \mathrm{H}_{2} \mathrm{O}\right)$ was added and the mixture was pre-equilibrated at $30^{\circ} \mathrm{C}$ for $15 \mathrm{~min}$ prior to initiation of the reaction by the addition of substrate ( $45.6 \mathrm{mM} p$-nitrophenyl disodium orthophosphate: $2 \mathrm{ml}$ ). Timed samples $(2 \mathrm{ml})$ were quenched in $4 \mathrm{ml}$ $0.2 \mathrm{M} \mathrm{NaOH}$ and the liberated $p$-nitrophenol was estimated spectrophotometrically at $405 \mathrm{~nm}$ versus a suitable $p$-nitrophenol standard. Phosphatase specific activity (unit) is defined as $\mathrm{nmol} p$-nitrophenol liberated $\mathrm{min}^{-1}$ ( $\mathrm{mg}$ bacterial protein $)^{-1}$, with bacterial protein determined by the Lowry method. Experiments used cells withdrawn from two or three independent chemostats for each strain. In the latter case data are expressed as means \pm SEM. Where two chemostats were used the data (three determinations from each chemostat) were pooled to give the data from two experiments. The mean \pm SEM for the six samples was generally within $10-15 \%$.

To test the effect of a heavy metal, activator or inhibitor, the cells were pre-equilibrated for $1.5 \mathrm{~h}$ in the reaction mixture at pH 5 (MES buffer), pH 7 (MOPS buffer) or pH 8.5 (Tricine buffer; see below) containing the agent under test prior to the addition of $p$-nitrophenyl phosphate. Metal solutions were freshly prepared prior to their use, and controls established that no metal precipitation occurred in cell-free media. Where the quenched phosphatase reaction yielded a metal phosphate or hydroxide precipitate the solid material was allowed to settle out (1-2 h) prior to estimation of $p$-nitrophenol in the supernatant.

Buffer systems for phosphatase assay. Determination of $\mathrm{pH}-$ activity profiles ( $\mathrm{pH} 3-10)$ necessitated the use of several buffers (all $200 \mathrm{mM}$ ), as follows: $\mathrm{pH} \mathrm{3-4,} \mathrm{citric} \mathrm{acid/trisodium} \mathrm{citrate;}$ $\mathrm{pH} 4-6$, acetic acid/sodium acetate; $\mathrm{pH} 5, \mathrm{MES} / \mathrm{NaOH}$; pH 6-9, Tris/HCl; $\mathrm{pH} 7$, MOPS/NaOH; $\mathrm{pH} 8.5$, Tricine/ $\mathrm{NaOH}$; pH 9-10, sodium carbonate/sodium hydrogen carbonate. The use of two buffers at overlap $\mathrm{pH}$ values allowed for correction of effects of the buffer on enzyme activity. In general, little difference was observed, except that phosphatase activity was stimulated by $3 \cdot 8 \pm 0 \cdot 2$-fold at $\mathrm{pH} 9$ in Tris buffer as compared to carbonate buffer under the same conditions (mean $\pm \mathrm{sE}$, three experiments). Cell permeabilization was not required to visualize phosphatase activity (Hambling et al., 1987) but additional checks were made as appropriate by treatment with toluene/ethanol $(1: 9, \mathrm{v} / \mathrm{v})$ (Carter \& Dean, 1976).

Heavy metal accumulation by Citrobacter spp. Batch-grown cells (metal-unsupplemented) were harvested in the midexponential phase and challenged with either uranyl nitrate $\left[\mathrm{UO}_{2}\left(\mathrm{NO}_{3}\right)_{2} \cdot 6 \mathrm{H}_{2} \mathrm{O}\right]$ or lanthanum nitrate $\left[\mathrm{La}\left(\mathrm{NO}_{3}\right)_{3} \cdot 6 \mathrm{H}_{2} \mathrm{O}\right]$ $(1 \mathrm{mM})$ in a carrier solution of $2 \mathrm{mM}$ citrate $/ 20 \mathrm{mM}$ MOPS 
buffer, $\mathrm{pH} 7$, supplemented with $5 \mathrm{mM}$ glycerol 2-phosphate, as described previously (Macaskie et al., 1994b). The residual metal remaining in the supernatant following removal of the cells by centrifugation was assayed after $6 \mathrm{~h}$ and $24 \mathrm{~h}$ using arsenazo III, with metal uptake expressed as a percentage of the initial metal removed (Macaskie et al., 1994b).

\section{RESULTS AND DISCUSSION}

\section{Phosphatase activities of batch-grown cells, and heavy metal bioaccumulation}

Cultures of C. freundii NCIMB 11490 and NCIMB 7271, together with Citrobacter sp. N14 and the phosphatasedeficient mutant lp4a were harvested and challenged with uranyl ion $\left(\mathrm{UO}_{2}^{2+}\right)$ or lanthanum $\left(\mathrm{La}^{3+}\right)$ as described previously (Macaskie et al., 1994b). The high phosphatase activity for two specimen batches of strain N14, of 596 and 550 units, correlated with the removal of 97.4 and $98.0 \%$ of the $\mathrm{UO}_{2}^{2+}$, respectively, after $24 \mathrm{~h}$ and complete removal of $\mathrm{La}^{3+}$ after only $6 \mathrm{~h}$. The activity of batchgrown cells was intrinsically variable; the mean \pm SEM was determined at $327 \pm 3$ units in initial studies (Hambling et al., 1987) and was $236 \pm 19$ units (Macaskie et al., 1988) $302 \pm 165$ units (Butler et al., 1991), and $442 \pm 168$ units (Macaskie et al., 1994b) in later investigations.

In contrast to strain $\mathrm{N} 14, \mathrm{UO}_{2}^{2+}$ was not removed by the C. freundii strains (the phosphatase specific activity was $3.92 \pm 2.38$ units and $4.08 \pm 1.76$ units for strains NCIMB 11490 and NCIMB 7271; means \pm SEM from 9 and 11 experiments, respectively), or by the phosphatasedeficient mutant lp4a derived from strain N14. However, the $C$. freundii strains removed $100 \%$ of the $\mathrm{La}^{3+}$ after $24 \mathrm{~h}$. This was probably attributable to nonspecific precipitation of $\mathrm{La}$ upon the cells or within the periplasmic space with time; an identical result was obtained using the phosphatase-deficient mutant $1 \mathrm{p} 4 \mathrm{a}$, which indicated nonspecific bioaccumulation mechanisms. A previous study has demonstrated the high capacity of the periplasmic space and surface layers of the related Escherichia coli for deposited lanthanide ions (Bayer \& Bayer, 1991). Over a shorter timescale $(6 \mathrm{~h}), \mathrm{La}^{3+}$ was completely removed by strain N14 only; none was removed by the two $C$. freundii strains or the phosphatase-deficient mutant. These results, together with a previous demonstration of the removal of heavy metals by strain N14 (but not by the phosphatasedeficient mutant: Macaskie et al., 1994a), confirmed the participation of the phosphatase in heavy metal bioprecipitation.

Studies on metal bioaccumulation were done at neutral $\mathrm{pH}$, since previous work has shown that metal phosphates are more soluble at acidic $\mathrm{pH}$; here the correlation (Macaskie et al., 1994a) between phosphatase activity and metal desolubilization does not apply (Tolley et al., 1995). For a more realistic evaluation of acid phosphatase activity C. freundii was also assayed at $\mathrm{pH} 5$. The phosphatase specific activities were increased to $6.4 \pm 0.7$ units and $7 \cdot 1 \pm 0 \cdot 6$ units for strains NCIMB 11490 and NCIMB 7271 , respectively (means \pm sEM; eight experiments), but remained substantially lower than that of strain N14 [the phosphatase activity of batch-grown cells of this strain
( $>200$ units: see above) was similar at $\mathrm{pH} 5$ and $\mathrm{pH} 7$; Tolley et al., 1995].

A previous study concluded that the phosphatase specific activity of batch-grown cells of strain N14 increased approximately threefold during exponential growth (Butler et al., 1991). An increase was also seen if the cells were transferred to anaerobic conditions, even though further growth did not occur (Hallett et al., 1991). A corresponding increase was not observed with the $C$. freundii strains following a shift to anaerobiosis (not shown). Phosphatase activity was also monitored in batch cultures harvested during growth. In contrast to strain N14 (above) the increase in phosphatase activity was small for both $C$. freundii strains. The activity of late-exponentialphase cells $\left(\mathrm{OD}_{600}=>0.8\right)$ was increased as compared to mid-exponential-phase cells by $2 \cdot 3 \pm 0 \cdot 8$-fold and $1 \cdot 8 \pm 0.4$-fold at $\mathrm{pH} 7$ and 5 , respectively, for strain NCIMB 7271 and $1 \cdot 3 \pm 0 \cdot 2$-fold and $1 \cdot 2 \pm 0 \cdot 2$-fold at $\mathrm{pH} 7$ and 5, respectively, for strain NCIMB 11490 (means \pm sEM; six experiments).

These preliminary tests showed little similarity between the phosphatase activity of Citrobacter N14 and the C. freundii strains. The production of alkaline phosphatase, regulated via phosphate starvation (Wanner, 1993; see below), is well documented, but acid phosphatase production, regulated by carbon starvation in addition to various other stresses such as $\mathrm{pH}$ and anaerobiosis (see below), is less well understood. If it is argued that the metal-stress conditions in the original environment may have selected for constitutive phosphatase expression in strain N14 as a metal detoxification mechanism (see Introduction), growth in non-limiting batch cultures might not be expected to promote the expression of either phosphatase by the $C$. freundii strains. Against this, however, is the recent observation that E. coli, grown on carbon sources other than glucose, expresses acid phosphatase activity during batch growth (Rossolini et al., 1994). Subsequent experiments used continuous culture to compare phosphatase activities of the strains under steady-state conditions of nutrient limitation in order to express the activity of the phosphatases (where present) maximally.

\section{Alkaline phosphatase activities of Citrobacter spp. grown under phosphate limitation}

The production and activity of alkaline phosphatase is regulated via the pho regulon (Wanner, 1993) and, accordingly, the phosphatase activity of Citrobacter sp. N14 and C. freundii NCIMB 11490 was maximal at $\mathrm{pH} 8-8.5$ in cells withdrawn from phosphate-limiting continuous cultures (Fig. 1). The specific activity of the two strains was similar, at 200 and 251 units for strains N14 and NCIMB 11490, respectively; this is shown as $100 \%$ for both strains (Fig. 1) for comparison. In accordance with earlier results using strain N14 (Hambling et al., 1987) toluenization of $C$. freundii NCIMB 11490 did not yield additional phosphatase activity at pH 8.5. It was concluded that alkaline phosphatase production by the two Citrobacter strains was similar. 


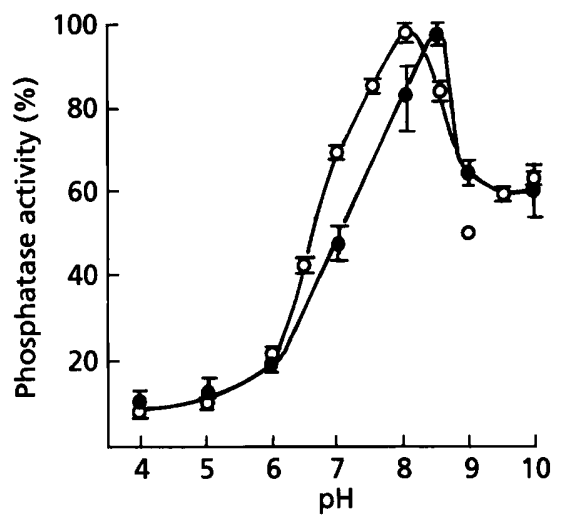

Fig. 1. Phosphatase activities of Citrobacter sp. N14 and C. freundii NCIMB 11490 grown in phosphate-limited continuous culture. The Citrobacter strains were grown as described in Methods at $D=0.5 \mu_{\max }$ (see text). Data (means \pm SEM) were from several replicate determinations at the $\mathrm{pH}$ values shown, in buffers appropriate to each $\mathrm{pH}$. For comparison the data are expressed as a percentage of the maximum activity; this corresponded to 200 units and 251 units for Citrobacter N14 $(O)$ and $C$. freundii (O), respectively.

\section{Acid phosphatase activities of Citrobacter spp. grown under carbon limitation}

The pho regulon is generally understood to regulate transcription of genes concerned with phosphate acquisition and utilization (above) but it has been shown also that one pho-regulated operon (ugp: Wanner, 1993) is regulated by both phosphate and carbon starvation at two separate promoters (Kasahara et al., 1991a). The carbonstarvation-inducible promoter is regulated by cyclic AMP and its receptor protein (CRP) which are more usually associated with carbon starvation responses (see Kasahara et al., 1991a). Although the production of acid phosphatase was maximal under carbon limitation in Klebsiella (Aerobacter) aerogenes (Bolton \& Dean, 1972), Salmonella typbimurium (Kier et al., 1977a) and Citrobacter sp. N14 (Hambling et al., 1987; Macaskie, 1990), in the latter case enzyme production was regulated additionally by the phosphorus status of the medium (Butler et al., 1991), and cross-talk is implied here, also. A dual regulation, and additional factors such as the $\mathrm{pH}$ of the medium and the oxygen tension during growth (Touati et al., 1987; Hallett et al., 1991; Jeong, 1992), may explain the variation between batches noted above, and justify the use of continuous culture to achieve a steady-state for study. The acid phosphatase of Citrobacter sp. N14 is homologous to the phoN product of $S$. typhimurium (Macaskie et al., $1994 b)$. Regulation of $p h o N$ by the $p h o P-p b o Q$ regulatory system is established (Kasahara et al., 1991b); this is responsible for responses to environmental stimuli (Groisman \& Saier, 1990; Miller et al., 1993).

The three Citrobacter strains were grown in carbonlimited continuous culture (Fig. 2). In each case the acid phosphatase activity was increased as compared to the activity in glycerol-batch cultures (cf. above). It should be noted that 'acid' phosphatase activity of $K$. aerogenes and

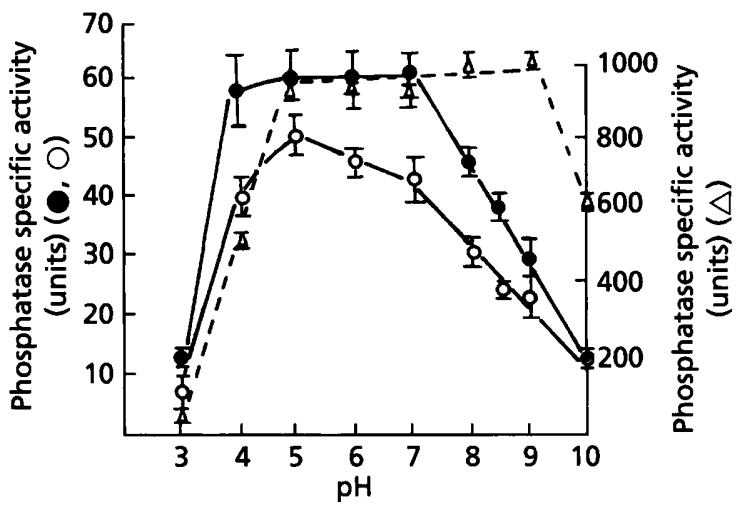

Fig. 2. Phosphatase activities of Citrobacter sp. N14 and C. freundii NCIMB 11490 and 7271 grown in carbon-limiting continuous culture. Details as for Fig. 1. Data are means \pm SEM pooled from several replicate samples from two chemostats (strains NCIMB 11490 and NCIMB 7271) or from a representative chemostat (strain N14: see text). O. C. freundii NCIMB 11490; O. C. freundii NCIMB 7271 (solid lines, left scale); $\triangle$, Citrobacter N14 (dashed line, right scale).

Citrobacter sp. N14 is, more correctly, the pooled contributions of acid and neutral phosphatase activities (Bolton \& Dean, 1972; Jeong, 1992). The $\mathrm{pH}$-activity profiles of whole cells show activity at $\mathrm{pH} 4-8$ (Fig. 2). It could be argued that the periplasmic $\mathrm{pH}$ differs from the $\mathrm{pH}$ of the bulk solution; however a similarly broad $\mathrm{pH}$ profile has been confirmed using purified Citrobacter N14 phosphatase (Jeong, 1992). An alternative argument could state that examination of an enzyme in vitro will not adequately portray the activity of an enzyme that may exist as a membrane-bound/periplasmic complex in vivo. The latter has been proposed for the PhoN phosphatase of S. typhimurium (Kier et al., 1977b). The periplasmic localization of the enzyme is well documented in this organism (see Kier et al., 1977b). During purification the Citrobacter sp. N14 enzyme behaved in a similar manner to that of S. typhimurium (Jeong, 1992). Additional confirmation of the periplasmic location of the phosphatase was provided by immunogold labelling studies (Jeong, 1992).

The phosphatase activity of strain N14 under carbonlimitation was approximately 20 -fold higher than that of the two C. freundii strains (Fig. 2). The data for the latter were pooled from two chemostats for each; representative data from one Citrobacter sp. N14 chemostat are shown (specific activity was approx. 1000 units); they were indistinguishable from specific activities obtained from two other chemostats, of 911 and 1018 units, respectively. Phosphatase activity was expressed at alkaline $\mathrm{pH}$ under carbon limitation by strain N14 but not by the $C$. freundii strains. The flat profile of the activity of the Citrobacter N14 enzyme might imply that the rate-limiting step is the entry of the artificial chromophore $p$-nitrophenyl phosphate through the outer membrane. However, cellular disruption using a French pressure cell did not yield additional activity, and other studies using cells grown under carbon (glycerol) limitation in an air lift fermenter 
Table 1. Effect of various inhibitors on acid, neutral and alkaline phosphatase activities of three Citrobacter strains

The effect of various agents at $1 \mathrm{mg} \mathrm{m}^{-1}$ final concentration was tested as described in Methods. The data (three determinations from each of two independent chemostats) were pooled to give a mean \pm SEM of within 10-15\%; mean values are shown. ND, Not determined. Numbers in bold type indicate a significant difference between the strains.

\begin{tabular}{|c|c|c|c|c|c|c|c|c|c|}
\hline \multirow[t]{4}{*}{ Test agent } & \multicolumn{9}{|c|}{ Phosphatase specific activity ( $\%$ of unsupplemented control) } \\
\hline & \multicolumn{3}{|c|}{ pH 5} & \multicolumn{3}{|c|}{ pH 7} & \multicolumn{3}{|c|}{ pH 8.5 } \\
\hline & \multicolumn{3}{|c|}{ Strain: } & \multicolumn{3}{|c|}{ Strain: } & \multicolumn{3}{|c|}{ Strain: } \\
\hline & 11490 & 7271 & N14 & 11490 & 7271 & N14 & 11490 & 7271 & N14 \\
\hline $\mathrm{Cd}^{2+}$ & $43 \cdot 0$ & $23 \cdot 4$ & 80.0 & $34 \cdot 4$ & 39.0 & 79.0 & $103 \cdot 7$ & $92 \cdot 7$ & 85.0 \\
\hline $\mathrm{Zn}^{2+}$ & $26 \cdot 3$ & $18 \cdot 4$ & $81 \cdot 5$ & $14 \cdot 1$ & $9 \cdot 0$ & 2.0 & $81 \cdot 7$ & 66.5 & $111 \cdot 5$ \\
\hline $\mathrm{Cu}^{2+}$ & $16 \cdot 6$ & $21 \cdot 6$ & $2 \cdot 5$ & ND & ND & ND & $98 \cdot 9$ & $97 \cdot 5$ & $91 \cdot 0$ \\
\hline $\mathrm{Ni}^{2+}$ & $112 \cdot 2$ & $67 \cdot 6$ & $84 \cdot 5$ & $85 \cdot 6$ & 65.0 & $73 \cdot 0$ & $79 \cdot 7$ & $96 \cdot 4$ & $103 \cdot 0$ \\
\hline $\mathrm{Co}^{2+}$ & $93 \cdot 1$ & $115 \cdot 0$ & $90 \cdot 0$ & 86.5 & $88 \cdot 9$ & 93.0 & $124 \cdot 0$ & $127 \cdot 6$ & $113 \cdot 5$ \\
\hline EDTA & $96 \cdot 2$ & $101 \cdot 9$ & $97 \cdot 0$ & $103 \cdot 0$ & $94 \cdot 0$ & $106 \cdot 5$ & $100 \cdot 0$ & $117 \cdot 6$ & $97 \cdot 5$ \\
\hline Phosphate & $99 \cdot 3$ & 95.9 & $92 \cdot 0$ & $100 \cdot 3$ & $95 \cdot 7$ & $100 \cdot 5$ & $96 \cdot 8$ & 86.5 & $93 \cdot 0$ \\
\hline Fluoride & $18 \cdot 5$ & $21 \cdot 8$ & $9 \cdot 0$ & 33.9 & $39 \cdot 1$ & $32 \cdot 5$ & $70 \cdot 5$ & $73 \cdot 7$ & $25 \cdot 5$ \\
\hline Formaldehyde & $83 \cdot 1$ & $79 \cdot 6$ & $71 \cdot 0$ & $73 \cdot 5$ & $76 \cdot 3$ & $69 \cdot 0$ & $84 \cdot 0$ & $106 \cdot 6$ & $72 \cdot 0$ \\
\hline Tartrate & $90 \cdot 5$ & $85 \cdot 7$ & $84 \cdot 0$ & $103 \cdot 6$ & $95 \cdot 6$ & $96 \cdot 5$ & $106 \cdot 1$ & $122 \cdot 0$ & $95 \cdot 0$ \\
\hline Imidazole & $107 \cdot 2$ & $97 \cdot 9$ & $109 \cdot 0$ & 98.5 & $98 \cdot 8$ & $93 \cdot 0$ & $82 \cdot 6$ & $87 \cdot 3$ & $86 \cdot 5$ \\
\hline Theophylline & 95.9 & $87 \cdot 6$ & 131.0 & ND & ND & ND & 94.9 & $100 \cdot 4$ & $88 \cdot 5$ \\
\hline Phenylalanine & $103 \cdot 5$ & $95 \cdot 9$ & 92.5 & $100 \cdot 6$ & $101 \cdot 6$ & $95 \cdot 5$ & $108 \cdot 1$ & $89 \cdot 5$ & $93 \cdot 0$ \\
\hline
\end{tabular}

(Macaskie et al., 1995a) or using lactose in fed-batch culture (Macaskie et al., 1995b) yielded cultures with higher whole-cell phosphatase activities, of approximately 3000 and 1800 units, respectively. The use of acetate or citrate buffer to evaluate phosphatase activity at low $\mathrm{pH}$ is problematic since both ligands complex metals extensively. Although alkaline phosphatase activity is $\mathrm{Mg}^{2+}$ dependent (Ahlers, 1974; Cathala et al., 1975; Linden et al., 1977), the acid phosphatase of Citrobacter sp. N14 did not require $\mathrm{Mg}^{2+}$ for activity (Hambling et al., 1987). As an additional check, the phosphatase activity of the three Citrobacter strains was confirmed to be unaffected by $1 \mathrm{mg}$ EDTA $\mathrm{ml}^{-1}$.

\section{Comparison of acid-type phosphatases of Citrobacter freundii and Citrobacter sp. N14}

As a confirmation that similar enzymes were being compared in the three strains, the responses of the enzymes to some diagnostic inhibitors were investigated (Table 1). Negligible inhibition by phosphate was observed; similarly tartrate, imidazole and phenylalanine had little, if any, effect. A detailed discussion of the effects of the inhibitors is outside the scope of this investigation, since the objective was to compare the overall pattern of responses to the inhibitors under test. The effect of theophylline was, however, noteworthy, since a slightly inhibitory effect was seen with both $C$. freundii strains; in contrast, the enzyme of Citrobacter sp. N14 was stimulated by approximately $30 \%$ at $\mathrm{pH} 5$ (Table 1 ). A similar effect was observed previously (Hambling et al., 1987).

In accordance with previous studies (Hambling et al., 1987), formaldehyde and fluoride were inhibitory. At

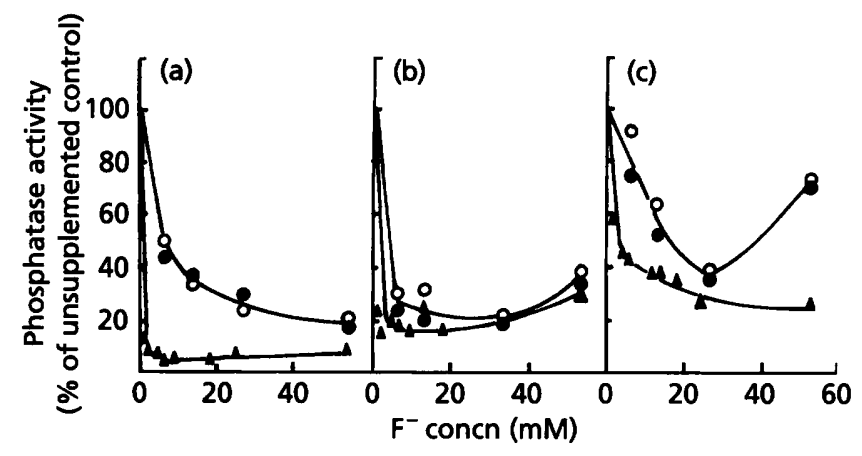

Fig. 3. Effect of fluoride ions on whole-cell phosphatase activity. The cells were pre-incubated in the presence of $\mathrm{NaF}$ as described in Methods at pH 5.0 (a), $\mathrm{pH} 7.0$ (b) and pH 8.5 (c). Phosphatase activity is shown as a percentage of the unsupplemented control for C. freundii NCIMB 11490 (O), C. freundii NCIMB $7271(O)$ and Citrobacter sp. N14 (A). The data (three determinations from each of two independent chemostats) were pooled to give a mean $\pm S E M$ of within $10-15 \%$.

$\mathrm{pH} 5$ and 7 the inhibition by formaldehyde was similar for the three strains (Table 1). The inhibitory effect of fluoride (Table 1) warranted further investigation (Fig. 3). The greater sensitivity of the Citrobacter sp. N14 enzyme at pH 5 was confirmed; in particular, at $5 \mathrm{mM} \mathrm{F}^{-} C$. freundii retained approximately $50 \%$ of the phosphatase activity (cf. the N14 enzyme, for which $>90 \%$ of the activity was lost: Fig. 3a). At the neutral pH (Fig. 3b) the inhibition of the three strains was similar. At $\mathrm{pH} 8.5$ the toxicity was less for all three strains as compared to $\mathrm{pH} 5$ but strain 


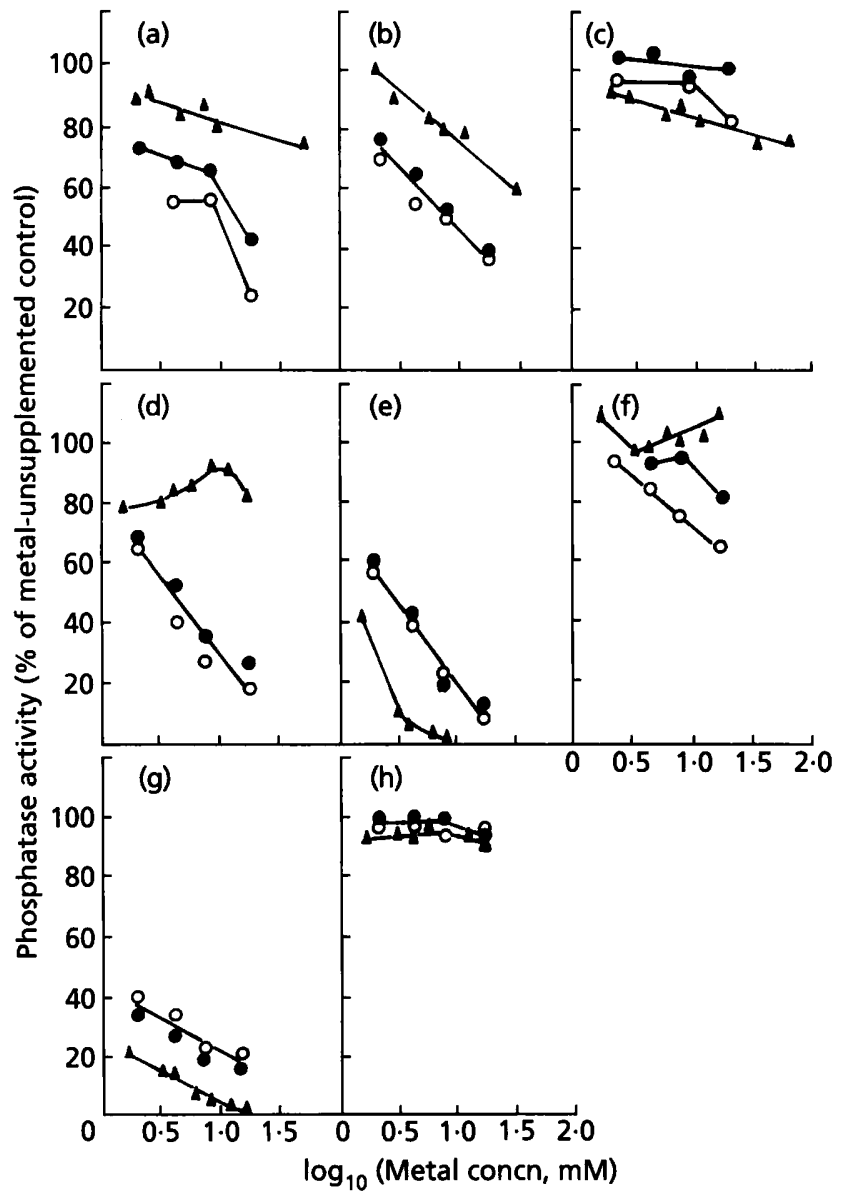

Fig. 4. Effect of heavy metals on whole-cell phosphatase activity. The cells were pre-incubated in the presence of heavy metals as described in Methods in the non-complexing buffers (Good et al., 1966) MES (pH 5.0; a, d, g) and MOPS (pH 7.0; b, e) or the complexing buffer Tricine ( $\mathrm{pH} 8.5 ; \mathrm{c}, \mathrm{f}, \mathrm{h}$ ). Phosphatase activity is expressed as a percentage of the unsupplemented control for cells challenged with $\mathrm{Cd}^{2+}(a, b, c), \mathrm{Zn}^{2+}(d, e, f)$ or $\mathrm{Cu}^{2+}(\mathrm{g}, \mathrm{h})$. O. C. freundii NCIMB 11490; O, C. freundii NCIMB 7271; $\triangle$, Citrobacter sp. N14. The data (three determinations from each of two independent chemostats) were pooled to give a mean \pm SEM of within $10-15 \%$.

N14 was still the most sensitive (Fig. 3c). Lower concentrations of fluoride were not tested, although the $K_{\mathrm{i}}$ value for $\mathrm{F}^{-}$against purified Citrobacter sp. N14 PhoN phosphatase isoenzymes has been determined as $1.2 \mathrm{mM}$ and $1.8 \mathrm{mM}$ using a Lineweaver-Burk plot (Jeong, 1992). This compares with a $K_{\mathrm{i}}$ value of $0.5 \mathrm{mM}$ for the $S$. typhimurium acid phosphatase (Weppelman et al., 1977).

\section{Effects of heavy metals on phosphatase activities of Citrobacter freundii and Citrobacter sp. N14}

The high Cd-tolerance of the phosphatase of the metalaccumulating Citrobacter sp. N14 was noted previously (Hambling et al., 1987; Jeong, 1992) and was probably attributable to the low concentration of thiol-containing amino acids in the protein (Jeong, 1992). At pH 5 the enzyme of strain N14 was relatively insensitive to $\mathrm{Cd}^{2+}$ and $\mathrm{Zn}^{2+}$ as compared to the $C$. freundii strains (Fig. 4a, d), but was more sensitive to $\mathrm{Cu}^{2+}$ at that pH (Fig. 4g). High tolerance to $\mathrm{Cd}^{2+}$ was seen also at $\mathrm{pH} 7$ (Fig. 4b), but at neutral $\mathrm{pH}$ the Citrobacter N14 enzyme was more sensitive to $\mathrm{Zn}^{2+}$ than the enzyme of the reference strains (Fig. $4 \mathrm{e}$ ). An apparently high tolerance to all three metals was observed for the three strains at $\mathrm{pH} 8.5$ (Fig. 4c, f, h) but these results are questionable since the buffer used (Tricine) would have complexed the metals; metal complexation is necessary to suppress the formation of hydroxylated species which form at neutral and high $\mathrm{pH}$ (Baes \& Mesmer, 1976; Hughes \& Poole, 1989, 1991). The different effects of $\mathrm{Cd}^{2+}$ and $\mathrm{Zn}^{2+}$ may be attributed to the chemistry of the two metals. $\mathrm{Cd}^{2+}$ behaves as a 'soft' cation, with high affinity for thiol groups, while $\mathrm{Zn}^{2+}$ is more 'hard' in nature; it can behave also as a Lewis acid and exert a strong polarizing effect on the target molecule (Hughes \& Poole, 1989). Possibly the toxic effect of this metal on the Citrobacter N14 phosphatase at pH 7 reflects a larger proportion of polarizable groups within the protein molecule, but why the effect should be seen at pH 7 only is not clear. This explanation may be too simplistic. Substantial hydrolysis of $\mathrm{Cd}^{2+}$ is largely confined to $\mathrm{pH}$ values above 7.0 (Hahne \& Kroontje, 1973; Baes \& Mesmer, 1976), while the hydrolysis of $\mathrm{Zn}^{2+}$ and $\mathrm{Cu}^{2+}$ begins at lower $\mathrm{pH}$ values. The $\mathrm{p} K_{\mathrm{a}}$ values of the aqua cations of $\mathrm{Cu}(\mathrm{II})$ and $\mathrm{Zn}(\mathrm{II})$ are $8 \cdot 0$ and $9 \cdot 0$, respectively (Hughes $\&$ Poole, 1991) and the formation of hydroxylated species accordingly begins at a lower $\mathrm{pH}$ with $\mathrm{Cu}^{2+}$ than with $\mathrm{Zn}^{2+}$ (Baes \& Mesmer, 1976). It is possible that an aqua carbonato species (Hughes \& Poole, 1991) may actually constitute the toxic agent at neutral $\mathrm{pH}$ in the case of $\mathrm{Zn}^{2+}$, and at $\mathrm{pH} 5$ in the case of $\mathrm{Cu}^{2+}$ (Fig. $4 \mathrm{e}, \mathrm{g})$. It was not possible to assess the toxicity of $\mathrm{Cu}^{2+}$ at pH 7 in the non-complexing (Good et al., 1966) buffer MOPS, since $\mathrm{Cu}(\mathrm{OH})_{2}$ precipitated out of the solution, but the similarity of the pattern of the $\mathrm{Cu}^{2+}$ toxicity at $\mathrm{pH} 5$ to that of $\mathrm{Zn}^{2+}$ toxicity at $\mathrm{pH} 7$ for the three strains should be noted. In each case the Citrobacter sp. N14 enzyme was the most susceptible. This is in contrast to the situation where the metals would have been present as the free divalent cations $\left(\mathrm{Cd}^{2+}\right.$ at $\mathrm{pH} 5$ and 7 , and $\mathrm{Zn}^{2+}$ at $\mathrm{pH} 5)$ or as the $\mathrm{Cd}(\mathrm{OH})^{+}$or $\mathrm{Zn}(\mathrm{OH})^{+}$species (Baes \& Mesmer, 1976); the $\mathrm{p} K_{\mathrm{a}}$ value of $\mathrm{Cd}(\mathrm{II})$ is 9.9 (cf. above) and accordingly the $\mathrm{Cd}^{2+}$ and $\mathrm{Cd}(\mathrm{OH})^{+}$species persist at pH 7 (Baes \& Mesmer, 1976). Further interpretation is not possible with the information available, but the pattern of metal toxicity may reflect differences in the structure, composition, charge or degree of hydration of the enzymes or, indeed, their possible localization in association with membranes or other high molecular mass structures in vivo (Kier et al., 1977b; B. C. Jeong and others, unpublished).

\section{Phosphatase activity and Cd-sensitivity of $C$. freundii 'trained' to tolerate $\mathrm{Cd}^{2+}$}

Using serial subcultures in progressively increasing concentrations of $\mathrm{Cd}^{2+}$ (see Methods) C. freundii NCIMB 11490 was 'trained' to $\mathrm{Cd}$ resistance. The growth rate after several subcultures at test concentrations of 50 and $100 \mu \mathrm{g} \mathrm{Cd}^{2+} \mathrm{ml}^{-1}$ was half that of the control value using 


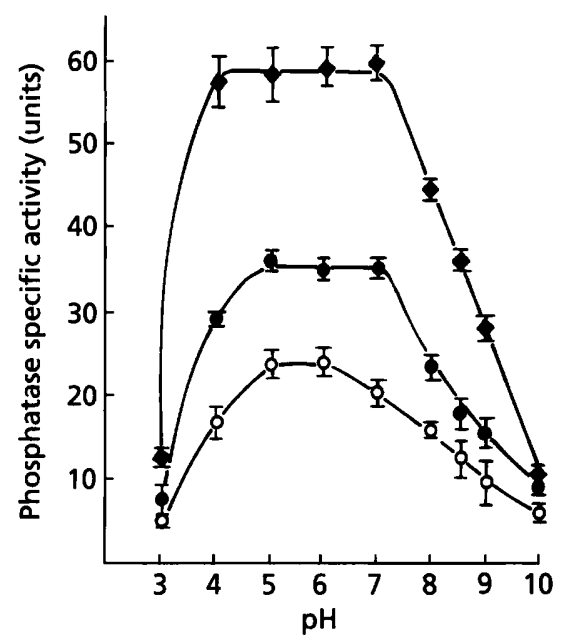

Fig. 5. Phosphatase activity of $C$. freundii NCIMB 11490 'untrained' $(\diamond)$ and 'trained' to $C d$ resistance at $50 \mu \mathrm{g} \mathrm{ml}^{-1}(0)$ and $100 \mu \mathrm{g} \mathrm{ml}^{-1}(0)$. The cells were cultured in chemostats supplemented with $\mathrm{Cd}^{2+}$ as appropriate at $D=0.5 \mu_{\max }$ as determined under appropriate conditions (see text). For growth in the Cd-'trained' cultures the $\mu_{\max }$ corresponded to $D=$ $0.28 \mathrm{~h}^{-1}$ at both concentrations, compared to $0.55 \mathrm{~h}^{-1}$ in the 'untrained' control. Data are from cells from two chemostats (see text).

Cd-unstressed cells. This was assigned as a new value of $\mu_{\max }$. Continuous cultures of 'trained' $C$. freundii NCIMB 11490 were maintained at $D=0.5 \mu_{\max }$. The phosphatase specific activity of the 'trained' cultures was apparently reduced as compared to the untrained culture (maintained at $D=0.5 \mu_{\max }$ as determined in 'untrained' cultures: Fig. 5), in contrast to the effect predicted if phosphatase overproduction was selected as a mechanism of metal detoxification (see Introduction). The $\mathrm{pH}$ profile remained constant. It was possible that selection within the chemostats for a metal-tolerant strain effectively increased the $\mu_{\max }$ value during the experiment, such that $D(=\mu)$ was not a constant proportion of $\mu_{\max }$. This could mean that the relative growth rate would be effectively decreasing with time at a constant $D$ with respect to $\mu_{\max }$ (i.e. a non-steady-state system). The growth-rate-dependence of phosphatase production has been noted previously (Hambling et al., 1987). Although this was not investigated, inspection of Fig. 5 shows this to be unlikely. The phosphatase activity of the cultures 'trained' to tolerate $100 \mu \mathrm{g} \mathrm{Cd}^{2+} \mathrm{ml}^{-1}$ was less than that of cultures 'trained' to $50 \mu \mathrm{g} \mathrm{ml}^{-1}$; the latter culture might have been expected to select for metal resistance more rapidly (i.e. to have been maintained at a progressively lower growth rate relative to $\mu_{\max }$ ), since the concentration of $\mathrm{Cd}^{2+}$ was less. For the above argument to apply, the culture 'trained' to $50 \mu \mathrm{g} \mathrm{Cd}^{2+} \mathrm{ml}^{-1}$ should have had less phosphatase activity than the culture 'trained' to $100 \mu \mathrm{g} \mathrm{ml}^{-1}$, yet the converse was observed (Fig. 5). It was concluded that, in contrast to a role for the phosphatase in metal resistance (see Introduction), continued exposure to $\mathrm{Cd}^{2+}$ reduces phosphatase production in $C$. freundii. The metal toxicity to the enzyme following 'training' was also investigated in order to discount the

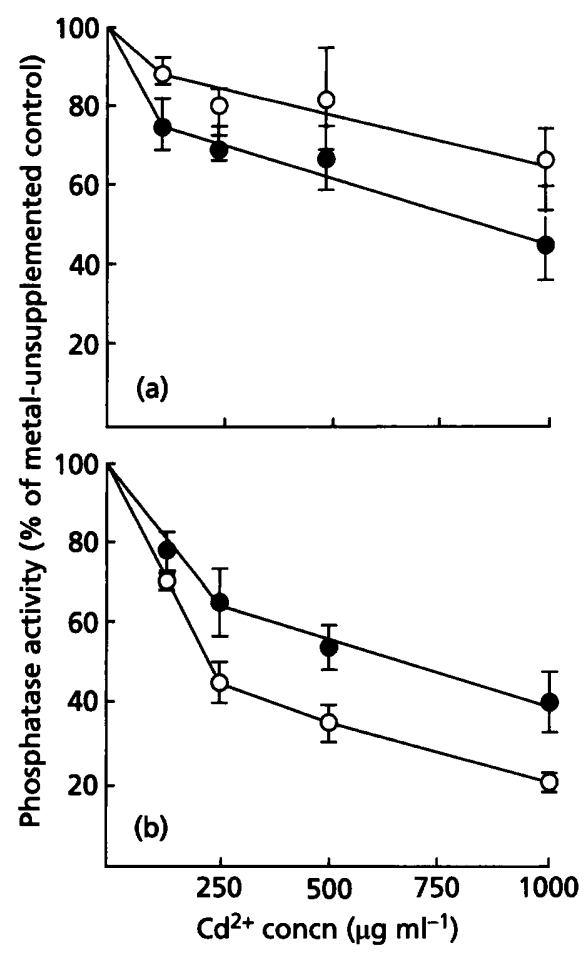

Fig. 6. $C d$ sensitivity of phosphatase activity of $C$. freundii NCIMB 11490 'trained' to Cd resistance $\left(100 \mu \mathrm{g} \mathrm{Cd}^{2+} \mathrm{ml}^{-1}\right)$ and challenged with $\mathrm{Cd}^{2+}$ at (a) $\mathrm{pH} 5$ (MES buffer) and (b) $\mathrm{pH} 7$ (MOPS buffer). O, Untrained $C$. freundii; $O, C$. freundii trained to resistance to $100 \mu \mathrm{g} \mathrm{Cd}^{2+} \mathrm{ml}^{-1}$.

possibility of production of an altered enzyme which was sensitive to Cd-toxicity.

\section{Sensitivity of $C$. freundii phosphatase to $\mathrm{Cd}^{2+}$ before and after 'training' of the cells to $\mathrm{Cd}$ tolerance}

No evidence was obtained for altered Cd resistance of the phosphatase enzyme during 'training' of $C$. freundii to $\mathrm{Cd}^{2+}$ (Fig. 6). The Cd-sensitivity of the phosphatase of the 'untrained' $C$. freundii was largely $\mathrm{pH}$-independent, discounting pH-dependent $\mathrm{Cd}$ speciation effects (Fig. 6a, b). Development of Cd-tolerance by the Cd-'trained' $C$. freundii gave altered responses of cellular phosphatase activity. At solution $\mathrm{pH}$ values of 5 and 7 the $\mathrm{Cd}$ resistance of the enzyme was increased (Fig. 6a) and decreased (Fig. $6 \mathrm{~b})$ respectively. It is not easy to interpret the biological significance of this, since the $\mathrm{pH}$ of the periplasm in juxtaposition to the enzyme is not known and would be difficult to determine. The apparently increased sensitivity of the enzyme to $\mathrm{Cd}$ at neutral $\mathrm{pH}$ was not significant at $100 \mu \mathrm{g} \mathrm{Cd}^{2+} \mathrm{ml}^{-1}$ (Fig. 6b) and could not have accounted for the effect seen in Fig. 5.

\section{Acid phosphatase activity in Citrobacter spp. and other Enterobacteriaceae}

The evidence presented here does not suggest that acid phosphatase overproduction is a metal detoxification response to deposit heavy metals harmlessly at the cell 
surface. Attempts to enhance phosphatase production by C. freundii by 'training' the cells to tolerance to $\mathrm{Cd}^{2+}$ were unsuccessful. Phosphatase overproduction by Citrobacter N14 does, however, appear to be atypical of the genus; indeed, the $p h o N$ gene encoding this enzyme (Macaskie $e t$ al., 1994b) is absent from C. freundii and also from E. coli (Kasahara et al., 1991b; Groisman et al., 1992), although E. coli has the PhoP-PhoQ regulatory system (Kasahara et al., 1992). $p h o N$ may be transferred laterally in the environment (Groisman et al., 1992), although no plasmids were found in strain N14. The question arises as to the identity of the acid phosphatase expressed in $C$. freundii strains under carbon limitation (which promotes expression of phoN: Kier et al., 1977a). Acid phosphatase activity is clearly seen in $C$. freundii (this communication) and $E$. coli (below), yet $p h o N$ is apparently absent (see above). This discrepancy was also noted by Rossolini $\mathrm{et} \mathrm{al}$. (1994), who demonstrated acid phosphatase activity in $E$. coli grown on carbon sources other than glucose. Recent work (Thaller et al., 1994, 1995a, b) suggests that enteric bacteria can produce two distinct periplasmic acid phosphatases, classified as type A (typified by PhoN of $S$. typhimurium and Citrobacter sp. N14, and PhoC of Morganella) or class B (e.g. the NapA enzyme of Morganella morganii: Thaller et al., 1995a). The latter type, apparently widespread amongst enteric bacteria, including Citrobacter spp. (Thaller et al., 1995b), characteristically requires $\mathrm{Mg}^{2+}$ for activity and is inhibited by EDTA. The latter was not observed for the carbon-starved $C$. freundii enzyme (Table 1). In addition, although the NapA of $M$. morganii is stimulated by $\mathrm{Co}^{2+}$ and $\mathrm{Zn}^{2+}$ (Thaller et al., 1995a) this was not observed here for $C$. freundii. Conversely, the $M$. morganii class $\mathrm{B}$ acid phosphatase is fluoride resistant (Thaller et al., 1995a), but the acid phosphatase of both strains of $C$. freundii was fluoride sensitive (Fig. 3), a property more in accordance with PhoN. Clearly the enterobacterial phosphatases warrant more extensive examination. In this context it should be noted that although acid phosphatase was well documented in Klebsiella (Bolton \& Dean, 1972), and subsequently identified in several strains as type A (M. C. Thaller, personal communication) pho $N$ is thought to be absent from this organism (e.g. Groisman et al., 1989). Further clarification is clearly required.

\section{ACKNOWLEDGEMENTS}

The experiments on metal accumulation by $C$. freundii strains were done by K. M. Bonthrone and P. Yong; their assistance, and the technical assistance of J. Ridley, is gratefully acknowledged. This work was supported in part by a grant from the European Community (BRITE-EURAM: contract BRE2/0199/C, project BE-5350), which also supported the search for plasmids in Citrobacter sp. N14 by Dr L. Diels. The authors wish to thank Dr M. C. Thaller for valuable discussions, and for allowing access to unpublished material.

\section{REFERENCES}

Ahlers, J. (1974). Kinetics of alkaline phosphatase from pig kidney, influence of complexing agents on stability and activity. Biochem $J$ $153,151-157$.
Aickin, R. M. \& Dean, A. C. R. (1979). Lead accumulation by Pseudomonas fluorescens and a Citrobacter sp. Microbios Lett 9, 55-66.

Aickin, R. M., Dean, A. C. R., Cheetham, A. K. \& Skarnulis, A. J. (1979). Electron microscope studies on the uptake of lead by a Citrobacter sp. Microbios Lett 9, 7-15.

Baes, C. F. \& Mesmer, R. E. (1976). The Hydrolysis of Cations. New York: Wiley.

Bahaj, A. S., Ellwood, D. C. \& Watson, J. H. P. (1989). Determination of magnetic susceptibility of loaded microorganisms in bio-magnetic separation. IEEE Trans Magnetics 25, 3809-3811.

Bayer, M. E. \& Bayer, M. H. (1991). Lanthanide accumulation in the periplasmic space of Escherichia coli B. J Bacteriol 173, 141-149.

Bolton, P. G. \& Dean, A. C. R. (1972). Phosphatase synthesis in Klebsiella (Aerobacter) aerogenes growing in continuous culture. Biochem J 127, 87-96.

Butler, A. J., Hallett, D. S. \& Macaskie, L. E. (1991). Phosphatase production by a Citrobacter sp. growing in batch culture, and use of batch cultures to investigate some limitations in the use of polyacrylamide gel-immobilized cells for product release. Enzyme Microb Technol 13, 716-721.

Carter, I. S. \& Dean, A. C. R. (1976). Hexokinase and glucosephosphoenolpyruvate phosphotransferase synthesis in Klebsiella aerogenes strains growing in continuous culture. Biocbem $J$ 166, 643-646.

Cathala, G., Chappelet-Tordo, D., Lazdunski, M. \& Brunel, C. (1975). Bovine kidney cell alkaline phosphatase. Catalytic properties and subunit interactions in the catalytic process and mechanism of $\mathrm{Mg}^{2+}$ stimulation. $J$ Biol Chem 250, 6046-6053.

Clark, P. J., Shama, G. \& Streat, M. (1992). Bioprecipitation of metals from wastewaters. Inst Chem Eng Res Event, UMIST, UK, pp. 308-310.

Clark, P. J., Shama, G. \& Streat, M. (1993). Metal recovery from a biofilm bioreactor. Inst Chem Eng Res Event, Birmingham, UK, pp. $420-422$.

Farmer, J. J. (1981). The genus Citrobacter. In The Prokaryotes, 1st edn, pp. 1140-1147. Edited by M. O. Starr, H. Stolp, H. Trüper, A. Balows \& H. G. Schlegel. Berlin, Heidelberg, New York: Springer.

Goddard, P. A. \& Bull, A. T. (1989). Accumulation of silver by growing and nongrowing populations of Citrobacter intermedius-B6. Appl Microbiol Biotechnol 31, 314-319.

Good, N. E., Winget, G. D., Winter, W., Connolly, T. N., Izawa, S. \& Singh, R. M. M. (1966). Hydrogen ion buffers for biological research. Biochemistry 5, 467-477.

Groisman, E. A. \& Saier, M. H., Jr (1990). Salmonella virulence: new clues to intramacrophage survival. Trends Biochem Sci 15, 30-33.

Groisman, E. A., Saier, M. H., Jr \& Ochman, H. (1989). Horizontal transfer of a phosphatase gene as evidence for mosaic structure of Salmonella genome. EMBO J 11, 1309-1316.

Hahne, H. C. H. \& Kroontje, W. (1973). Significance of $\mathrm{pH}$ and chloride concentration on the behaviour of heavy metal pollutants: mercury(II), cadmium(II) and lead(II). J Environ Qual 2, 444-450.

Hallett, D. S., Clark, P. \& Macaskie, L. E. (1991). Phosphatase production by a Citrobacter sp. growing in batch cultures retarded by anaerobic or osmotic stress and the effect of the osmoprotectant glycinebetaine. FEMS Microbiol Lett 78, 7-10.

Hambling, S. J., Macaskie, L. E. \& Dean, A. C. R. (1987). Phosphatase synthesis in a Citrobacter sp. growing in continuous culture. J Gen Microbiol 133, 2743-2749.

Hughes, M. N. \& Poole, R. K. (1989). Metals and Microorganisms. London: Chapman \& Hall. 
Hughes, M. N. \& Poole, R. K. (1991). Metal speciation and microbial growth - the hard (and soft) facts. J Gen Microbiol 137, 725-734.

Jeong, B. C. (1992). Studies on the atypical phosphatase of a metalaccumulating Citrobacter sp. DPhil thesis, University of Oxford.

Kasahara, M., Makino, K., Amemura, M. \& Shinagawa, H. (1991a). Dual regulation of the ugp operon by phosphate and carbon starvation at two interspaced promoters. J Bacteriol 173, 549-558.

Kasahara, M., Nakato, A. \& Shinagawa, H. (1991b). Molecular analysis of the Salmonella typhimurium phoN gene which encodes a nonspecific acid phosphatase. J Bacteriol 173, 6760-6765.

Kasahara, M., Nakato, A. \& Shinagawa, H. (1992). Molecular analysis of the Escherichia coli phoP-phoQ operon. $J$ Bacteriol 174, 492-498.

Kier, L. D., Weppelman, R. M. \& Ames, B. N. (1977a). Regulation of two phosphatases and a cyclic phosphodiesterase of Salmonella typhimurium. J Bacteriol 130, 420-428.

Kier, L. D., Weppelman, R. M. \& Ames, B. N. (1977b). Resolution and purification of three periplasmic phosphatases of Salmonella typhimurium. J Bacteriol 130, 399-410.

Linden, G., Chappelet-Tordo, D. \& Lazdunski, M. (1977). Milk alkaline phosphatase stimulation by $\mathrm{Mg}^{2+}$ and the properties of the $\mathrm{Mg}^{2+}$ site. Biocbim Biopbys Acta 483, 100-106.

Macaskie, L. E. (1990). An immobilized cell bioprocess for the removal of heavy metals from aqueous flows. $J$ Chem Technol Biotechnol 49, 357-379.

Macaskie, L. E. \& Dean, A. C. R. (1982). Cadmium accumulation by micro-organisms. Environ Technol Lett 3, 49-56.

Macaskie, L. E. \& Dean, A. C. R. (1984). Cadmium accumulation by a Citrobacter sp. J Gen Microbiol 130, 53-62.

Macaskie, L. E., Dean, A. C. R., Cheetham, A. K., Jakeman, R. J. B. \& Skarnulis, A. J. (1987). Cadmium accumulation by a Citrobacter sp.: the chemical nature of the accumulated metal precipitate and its location on the bacterial cells. J Gen Microbiol 133, 539-544.

Macaskie, L. E., Blackmore, J. D. \& Empson, R. M. (1988). Phosphatase overproduction and enhanced uranium accumulation by a stable mutant of a Citrobacter sp. isolated by a novel method. FEMS Microbiol Lett 55, 157-162.

Macaskie, L. E., Empson, R. M., Cheetham, A. K., Grey, C. P. \& Skarnulis, A. J. (1992). Uranium bioaccumulation by a Citrobacter sp. as a result of enzymically mediated growth of polycrystalline $\mathrm{HUO}_{2} \mathrm{PO}_{4}$. Science 257, 782--784.

Macaskie, L. E., Jeong, B. C. \& Tolley, M. R. (1994a). Enzymicallymediated biomineralization of heavy metals: application to the removal of americium and plutonium from aqueous flows. FEMS Microbiol Rev 14, 351-368.

Macaskie, L. E., Bonthrone, K. M. \& Rouch, D. A. (1994b). Phosphatase-mediated heavy metal accumulation by a Citrobacter sp. and related enterobacteria. FEMS Microbiol Lett 121, 141 146.

Macaskie, L. E., Empson, R. M., Fan, L. \& Tolley, M. R. (1995a). Enzymically mediated uranium accumulation and uranium recovery using a Citrobacter immobilized as a biofilm within a plug flow reactor. J Chem Technol Biotechnol 63, 1-16.

Macaskie, L. E., Hewitt, C. J., Shearer, J. A. \& Kent, C. A. (1995b). Biomass production for the removal of heavy metals from aqueous solution at low $\mathrm{pH}$ using growth decoupled cells of a Citrobacter sp. Int Biodeterior \& Biodegradat (in press).

Miller, S. I., Loomis, W. P., Alpuche-Aranda, C., Behlau, I. \& Hohmann, E. (1993). The PhoP virulence regulon and live oral Salmonella vaccines. Vaccine 11, 122-125.

Rossolini, G. M., Thaller, M. C., Pezzi, R. \& Satta, G. (1994). Identification of an Escherichia coli periplasmic acid phosphatase consisting of a $27 \mathrm{kDa}$ polypeptide component. FEMS Microbiol Lett 118, 167-174.

Thaller, M. C., Berlutti, F., Schippa, S., Lombardi, G. \& Rossolini, G. M. (1994). Characterization and sequence of $\mathrm{PhoC}$, the principal phosphate-irrepressible acid phosphatase of Morganella morganii. Microbiology 140, 1341-1350.

Thaller, M. C., Lombardi, G., Berlutti, F., Schippa, S. \& Rossolini, G. M. (1995a). Cloning and characterization of the NapA acid phosphatase/phosphotransferase of Morganella morganii: identification of a new family of bacterial acid phosphatase-encoding genes. Microbiology 141, 147-154.

Thaller, M. C., Berlutti, F., Schippa, S., lori, P., Passariello, C. \& Rossolini, G. M. (1995b). Heterogeneous patterns of acid phosphatases containing low molecular mass polypeptides in members of the family enterobacteriaceae. Int $J$ Syst Bacteriol (in press).

Tolley, M. R., Strachan, L. F. \& Macaskie, L. E. (1995). Lanthanum accumulation from acidic solutions using a Citrobacter sp. immobilized in a flow-through bioreactor. $J$ Ind Microbiol 14, 271-280.

Touati, E., Dassa, J. \& Boquet, P. L. (1987). In Phosphate Metabolism and Cellular Regulation in Microorganisms, pp. 31-40. Edited by A. Torriani-Gorini, F. G. Rothman, S. Silver, A. Wright \& E. Yagil. Washington, DC: American Society for Microbiology.

Wanner, B. (1993). Gene regulation by phosphate in enteric bacteria. $J$ Cell Biochem 51, 47-54.

Watson, J. H. P. \& Ellwood, D. C. (1987). Biomagnetic separation and extraction process. IEEE Trans Magnetics 23, 3751-3752.

Weppelman, R., Kier, L. D. \& Ames, B. N. (1977). Properties of two phosphatases and a cyclic phosphodiesterase of Salmonella typhimurium. J Bacteriol 130, 411-419.

Received 4 January 1995; revised 9 May 1995; accepted 16 May 1995. 